\title{
EDITORIAL
}

\section{5-2020: 25 years of Modern Italy}

2020 is special for Modern Italy because it marks 25 years since the journal's foundation in 1995. As those who remember the early days will affirm, it has been a remarkable quartercentury for Italian Studies. Hard-copy subscribers will see a salute to the $25^{\text {th }}$ anniversary on their issue covers in 2020, and within them, the occasion will be marked in further ways. Most specifically, we have commissioned some research on the journal's history, which has yielded some interesting results about ways the journal has changed over the years. Our analysis will be made available in an editorial to be published in issue 25.3 (August). Coincidentally, 2020 also marks the $25^{\text {th }}$ anniversary of the Journal of Modern Italian Studies, to which we send cordiali saluti.

For Modern Italy 2020 begins with the current, regular issue. It contains five articles that exemplify the diversity of research for which the journal has become known. Cecilia Brioni's article on 'Shorn capelloni' explores the meaning of violent attacks on Italian men who grew their hair long in the 1960s. Attilio Scaglione's article surveys the effectiveness of the addiopizzo, an anti-mafia strategy in $21^{\text {st }}$ century Palermo. Amy King examines the politicised memories of an arson attack in 1970s Rome. Bertrand Marilier analyses the thought of Giovanni Papini in early twentiethcentury Florence. And finally, in 'Fascist Samurais', Michele Monserrati explores the way Italian fascism sought to incorporate their Japanese allies into the 'Aryan' doctrine - continuing the themes of race and Asia showcased in recent special issues (23.4 and 24.4). The current issue also contains a substantial and wide-ranging book review section, thanks to the indefatigable efforts of our book review editors.

The first special issue of 2020, due out in May, will be on 'Transcultural Exchanges and Encounters in Italy'. It reflects growing interest in Italy's place in the world, and the world's place in Italy - an interest that was most recently explored in the Italy-Asia issue. 2020's second special issue, and the year's last, will present a range of research selected from 2019's highly successful ASMI Summer School, held at the University of Milan. It continues the transcultural theme, focusing on 'Italians beyond Italy/Italy beyond Italians'. The collection, mostly by early-career scholars, will point the way to another quarter century of research on modern Italy, in a more globalised world. To make sure that Modern Italy's local early days are not forgotten in a rush of global thinking, we intend to close the anniversary year by inviting several senior figures to collaborate in a roundtable discussion on the past - and the future - of Italian Studies.

2020 is also special for the general editors: it will be the sixth and final year of our tour of duty. We feel privileged that our editorship has coincided with this anniversary. It is too early to say goodbye, but it is never too early to say thank you, so we would like to take this opportunity to express our appreciation to those behind the scenes who make the journal what it is: the editorial board members who generously give advice; our associate editors Andrea Hajek and Giacomo Lichtner; our book review editors Roberta Colbertaldo, Milena Sabato, Giovanna Summerfield, Nicolas Virtue, and Joseph Viscomi; and a wide array of willing referees. All contribute their 
labour with no material reward, and, in the case of referees, anonymously. We also acknowledge the work of our editorial assistant, Alessia Zinnari, and the team at Cambridge University Press, particularly our content manager, Rachael Lowther. Tante grazie e buona lettura.

Penelope Morris and Mark Seymour 